\title{
Use of Medical Applications By Students During
}

\section{Emergency Medical Training}

\section{Acil Tıp Eğitimi Sırasında Öğrenciler Tarafından Tıbbi Uygulamaların Kullanımı}

\author{
Mustafa Yilmaz, Mehmet Çağrı Göktekin
}

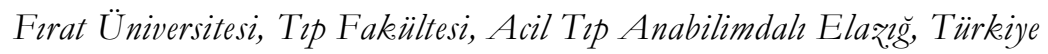

\begin{abstract}
Introduction: This study aimed to determine the frequency of medical application (medical app) use in emergency medical training by 6th year (senior year) medical faculty students and the contribution of these applications to learning.

Materials and Methods: The population of this study consisted of 6th year (senior year) medical students who completed their emergency medical internship training. Online questionnaires were prepared based on literature data and experience, and the students were asked to complete these questionnaires on a voluntary basis.

Results: Surveys were completed by 95 students who agreed to participate, 45 of these students who did not receive Emergency Medicine internship were excluded from the study.. Of the participants, $38.6 \%(n=22)$ were female and $61.4 \%(\mathrm{n}=35)$ were male, while $56.1 \%(\mathrm{n}=$ 32) were between the ages of $18-24$ and $43.9 \%(n=25)$ were between the ages of $25-29$. Of the students, $68 \%$ thought that, compared to the other branches, medical app use increased to a greater extent during emergency medical training. It was found that $70 \%$ of the students used medical apps in the emergency room to access information such as drug dosage and indications, while $62 \%$ used medical apps to learn about ECG. It was found that $80 \%$ of the students never or rarely used applications that contained medical calculators.

Conclusion: Medical app use by senior medical faculty students during their emergency medical training is increasing. Students use applications on drugs, ECG and radiological evaluation more frequently, compared to applications on medical dictionary, anatomy and medical calculators.
\end{abstract}

Key Words: Emergency education, Mobile application, Smartphone, Student

\begin{abstract}
ÖZET
Amaç: Tıp Fakültesi son sınıf öğrencilerinin acil tıp eğitimi sırasında medikal uygulama kullanımlarının sıklığının ve eğitimlerine katkısının tespit edilmesi amaçlandi.

Gereç ve Yöntem: Çalışmamız evrenini acil tıp staj eğitimini tamamlayan tıp fakültesi son sınıf öğrencileri oluşturmaktadır. Katılımcılara daha önceden literatür bilgilerinden ve deneyimlerden faydalanılarak oluşturulan anketler online olarak hazırland1 ve ögrencilerin gönüllü olarak doldurulması istendi. Anket 3 bölümden oluşturuldu. Birinci bölümde katılımcıları tanımlayıcı bilgiler, ikinci bölümde; öğrencilerin medikal uygulamaların kullanım sıklıkları ve kullanılan uygulamaların içerikleri hakkında bilgiler, üçüncü bölümde ise öğrencilerin medikal uygulamalar hakkındaki düşüncelerinin tespit edilmesi amaçladı.

Bulgular: Araştırmamıza katılmayı kabul eden 95 öğrenci tarafından anketler tamamlanmıştır. Bu öğrencilerin 45'i Acil Tıp stajı almadığından dolayı çalışma dışı bırakıldı. Kat1limciların \% 38,6 ( $\mathrm{n}=22)$ kadın iken \%61,4 $(\mathrm{n}=35)$ erkek idi. \% 56,1 ( $\mathrm{n}=32)$ 18-24 yaş arasında iken \%43,9 $(n=25)$ 25-29 yaş aralığında yer alıyordu. Öğrencilerin $\% 68$ 'i acil tıp eğitimleri sırasında Medical App uygulama oranlarının diğer branşlara oranla daha da arttığ düşüncesinde idi. Öğrencilerin \% 70'inin acil serviste; ilaç doz, endikasyonu gibi bilgilere ulaşmak, \% 62'sinin ise EKG öğrenmek amacıyla medikal uygulamaları kullandığ tespit edildi. Öğrencilerin \%80'inin ise hiç ya da nadiren medikal hesap makinası içeren programları kullandığı tespit edildi.

Sonuç: Tip fakültesi son sınıf öğrencilerin Acil tıp eğitimleri sırasında Medical App kullanma oranları artmaktadır. İlaç, EKG ve radyolojik değerlendirme içeren programları tıp sözlügü, anatomi ve medikal hesap makinası içeren programlara göre daha fazla kullanmaktadir.
\end{abstract}

Anahtar Kelimeler: Acil eğitimi, Akıllı telefon, Mobil uygulama, Öğrenci 


\section{Introduction}

The rapid increase in the number of mobile devices in recent years has created an environment in which unlimited resources are always at the disposal of a user. A variety of medical applications have been developed in the field of healthcare for numerous purposes, such as medical journals, medical calculators, interactive applications, drug indications, contraindications, formulation, trade names, determining the drugs to be used in the diagnosis and treatment of diseases, preparation for exams, and increasing and accessing medical knowledge $(1,2)$. Many studies have shown that medical applications (medical app) developed for healthcare professionals are beneficial for and increasingly used by them, owing to their contribution to the development of healthcare knowledge and skills (3-5). Instant access to information helps reinforce knowledge through repetition and makes mobile devices a valuable contributor to traditional learning resources (6). Medical apps are therefore frequently preferred by medical students, as they provide faster access to information. According to a survey conducted in the United Kingdom, $84 \%$ of medical students said that smartphones and the relevant medical apps were very helpful in medical education (7). In the literature, there are numerous studies conducted in different countries regarding the use of medical apps by medical students (8-12).

However, there are limited studies about the use of medical applications by students during emergency medical training. It is known that emergency medicine is a field in which students show greater interest in terms of clinical practice, and that they often use the Internet for disease diagnosis and treatment planning. Learning the most common reasons for medical app use by students during emergency medical training will also provide useful information about the basic training areas in which they need assistance or repetition. The aim of this study was to obtain information about the use of medical apps by senior medical faculty students in emergency medical training and to determine the general opinions of students on medical apps.

\section{Materials and Methods}

The population of this study consisted of 6th year (senior year) medical students who completed emergency medical training. The medical faculty involves a six-year education. In their last year, students work as intern physicians in different departments through rotations (between Internal
Medicine, Cardiology, Paediatrics, General Surgery and Emergency Medicine) in order to improve their medical practice and skills. In our university, a twomonth emergency medical training is given to senior medical faculty students. Online questionnaires were prepared based on literature data and experience, and the students were asked to complete these questionnaires on a voluntary basis $(11,13)$. The questionnaire consisted of three sections. The first section included questions on descriptive characteristics of the participants, the second section included questions on the frequency of medical app use and the contents of these applications, and the third section included questions on the students' opinions about medical apps. Surveys were completed by 95 students who agreed to participate in our study. 45 of these students who did not receive Emergency Medicine internship were excluded from the study.

Statistical Analysis: After data collection, statistical analyses were performed by using the SPSS 21.0 package program. Numerical data were expressed as mean \pm standard deviation and median (minimummaximal), and qualitative data as percentages. Cronbach's alpha value was calculated as 0.80 .

\section{Results}

Fifty students participated in the study. Of the participants, $38.6 \%(\mathrm{n}=22)$ were female and $61.4 \%$ $(\mathrm{n}=35)$ were male, while $56.1 \%(\mathrm{n}=32)$ were between the ages of $18-24$ and $43.9 \%(n=25)$ were between the ages of 25-29. General information about students' smartphone usage are given in Table 1.

It was found that $70 \%$ of the students used medical apps in the emergency room to access information such as drug dosage and indications, while $62 \%$ used medical apps to learn about ECG. It was found that $80 \%$ of the students never or rarely used applications that contained medical calculators. The reasons for and frequency of medical apps use in the emergency department by the students are given in Table 2 .

The students' positive opinions regarding medical apps included their view that these applications contribute to their education, that these applications increased their medical knowledge, and that they will continue to use medical apps after graduation. Negative opinions stated by the participants included their annoyance at the advertisements in medical apps. Interestingly, $42 \%$ of the students disagreed with the view that medical apps reduce the need for course books/lecture notes. The opinions of students about medical apps are given in Table 3 . 
Table 1. General information about students' smartphone usage

\begin{tabular}{cl}
\hline & $\mathrm{N}(\%)$ \\
\hline Smartphone Usage Time (Year) & \\
$<2$ year & $4(7,0)$ \\
$2-3$ & $13(22,8)$ \\
$4-6$ & $35(61,4)$ \\
$>7$ & $5(8,8)$ \\
Access to medical information & \\
Internet Search sites & $29(58)$ \\
Book for the Specialty Exam in Medicine & $12(24)$ \\
Medical App & $4(8)$ \\
Textbook & $5(10)$ \\
Number of Medical Applications & \\
$6-10$ & $41(82)$ \\
$11-15$ & $8(16)$ \\
& $1(2)$ \\
\hline
\end{tabular}

Table 2. Reason for and frequency of medical apps use in the emergency department

\begin{tabular}{lccccc}
\hline Reason for Using Medical App & Never & Rarely & Occasionally & Frequently & Very Frequently \\
\hline $\begin{array}{l}\text { Learn about drug dose } \\
\text { indication }\end{array}$ & $1(\% 2)$ & $2(\% 4)$ & $12(\% 24)$ & $19(\% 38)$ & $16(\% 32)$ \\
To evaluate ECG samples & $6(\% 12)$ & $7(\% 14)$ & $6(\% 12)$ & $19(\% 38)$ & $12(\% 24)$ \\
To evaluate radiological images & $4(\% 8)$ & $6(\% 12)$ & $16(\% 32)$ & $18(\% 36)$ & $6(\% 12)$ \\
Case evaluations & $8(\% 16)$ & $6(\% 12)$ & $20(\% 40)$ & $10(\% 20)$ & $6(\% 12)$ \\
Preparation for the Specialty & $9(\% 18)$ & $7(\% 14)$ & $18(\% 36)$ & $12(\% 24)$ & $4(\% 8)$ \\
Exam in Medicine & $12(\% 24)$ & $19(\% 38)$ & $13(\% 26)$ & $4(\% 8)$ & $2(\% 4)$ \\
Reading Papers & $7(\% 14)$ & $19(\% 38)$ & $15(\% 30)$ & $6(\% 12)$ & $3(\% 6)$ \\
Medical Dictionary & $7(\% 14)$ & $18(\% 36)$ & $17(\% 34)$ & $5(\% 10)$ & $3(\% 6)$ \\
Anatomy & $26(\% 52)$ & $14(\% 28)$ & $7(\% 14)$ & $2(\% 4)$ & $1(\% 2)$ \\
Medical Calculator & & & & \\
Number of participants $=50$ & & & & & \\
\hline
\end{tabular}

\section{Discussion}

The information that can be accessed easily, quickly and from anywhere at any time using the mobile devices offer benefits in many areas such as transportation, education, tourism and healthcare. For this reason, healthcare professionals and medical students frequently access information through mobile devices or computers, and this practice has become a part of their training. Many studies have been performed regarding the access of information by medical students via mobile devices and applications.
Emergency medical training is one of the fundamental aspects of medical education. After graduating from six years of medical education, medical students in Turkey begin their work in the emergency departments of city or rural hospitals. This increases the students' interest in emergency medical training, but also leads them to become concerned after graduation about their competence and proficiency in emergency patient management. In their study on 288 senior year medical faculty students, Yalcinoglu et al. found that the students were the most concerned about dealing with emergency patients (70.5\%) (14). The aim of the present study was to investigate the most common reasons for medical app usage in the 
Table 3. Students' Opinions about Medical Apps

\begin{tabular}{|c|c|c|c|c|c|}
\hline & $\begin{array}{l}\text { Strongly } \\
\text { Disagree }\end{array}$ & Disagree & Undecided & Agree & $\begin{array}{l}\text { Strongly } \\
\text { Agree }\end{array}$ \\
\hline $\begin{array}{l}\text { I tend to make more use of } \\
\text { emergency department medical apps } \\
\text { more. }\end{array}$ & $1(2,0)$ & $9(18,0)$ & $6(12,0)$ & $22(44,0)$ & $12(24,0)$ \\
\hline $\begin{array}{l}\text { Medical apps contribute to the faculty } \\
\text { courses. }\end{array}$ & $4(8,0)$ & $2(4,0)$ & $9(18,0)$ & $29(58,0)$ & $6(12,0)$ \\
\hline $\begin{array}{l}\text { Medical apps increase my knowledge } \\
\text { on drugs. }\end{array}$ & $2(4,0)$ & $1(2,0)$ & $6(12,0)$ & $27(54,0)$ & $14(28,0)$ \\
\hline $\begin{array}{l}\text { Medical apps increase my knowledge } \\
\text { on diseases. }\end{array}$ & $2(4,0)$ & $2(4,0)$ & $6(12,0)$ & $33(66,0)$ & $7(14,0)$ \\
\hline $\begin{array}{l}\text { I will continue to use medical apps } \\
\text { after I graduate. }\end{array}$ & $2(4,0)$ & $1(2,0)$ & $6(12,0)$ & $28(56,0)$ & $13(26,0)$ \\
\hline $\begin{array}{l}\text { Every medical faculty student should } \\
\text { use medical apps. }\end{array}$ & $2(4,0)$ & $3(6,0)$ & $14(28,0)$ & $22(44,0)$ & $9(18,0)$ \\
\hline $\begin{array}{l}\text { I trust the accuracy of the medical } \\
\text { information found in medical apps. }\end{array}$ & $1(2,0)$ & $4(8,0)$ & $22(44,0)$ & $23(46,0)$ & $0(0.0)$ \\
\hline $\begin{array}{l}\text { I find the advertisements in medical } \\
\text { apps annoying. }\end{array}$ & $1(2,0)$ & $3(6,0)$ & $4(8,0)$ & $19(38,0)$ & $23(46,0)$ \\
\hline $\begin{array}{l}\text { I think my need for course } \\
\text { books/lecture notes decreased after I } \\
\text { started using medical apps. }\end{array}$ & $3(6,0)$ & $18(36,0)$ & $13(26,0)$ & $14(28,0)$ & $2(4,0)$ \\
\hline
\end{tabular}

emergency department by the students, who frequently make use of mobile phones. It was found that the most commonly used applications were those that evaluate and provide information on drugs, ECG and radiological images, while less commonly used applications included those for reading medical papers and applications containing medical dictionaries and anatomical information. Medical calculator applications, on the other hand, were rarely used. Furthermore, $68 \%$ of the students were of the opinion that, compared to the other branches, medical app use increased to a greater extent during emergency medical training.

In their study conducted on medical students, residents and faculty members in a Canadian University, Jill T. et al. found that the most commonly reported uses of mobile devices in all of the groups were finding drug information $(73.5 \%)$, performing clinical calculations $(57.9 \%)$ and taking notes $(51.6 \%)$. They reported that more than $50 \%$ of $3 \mathrm{rd}$ and 4 th year students and residents used android apps on mobile devices to find drug information (15). In the present study, it was determined that more than $70 \%$ of the students used medical apps in the emergency department to find the doses of the drugs used in patient treatment planning and to identify the commercial names of the drugs that are prescribed. As such, medical students needed to use medical apps in order to remember the active substances of drugs and to recall the doses and commercial names of the drugs during practice. This suggests that they have problems in combining the information they acquired in the pharmacology course with actual clinical practice.

Similar to drug use, ECG was found to be the second main subject in which students felt a shortcoming in their education. Most clinical doctors, including those in general practice, are expected to have sufficient knowledge to evaluate ECG results, such that they can make an accurate diagnosis and decide on patient management or appropriately refer patients to other departments. For this reason, ECG training is given in different branches as part of the medical education curriculum. Our experience and current studies show that most medical students do not feel competent in evaluating ECG results $(16,17)$. In their study on medical app use, Sayedalamina et al. found that only $3 \%$ of students used medical apps containing ECG guides, and that the rate of instant ECG evaluation was $2.4 \% 8$. In our study, $38 \%$ of the students reported that they frequently used medical apps for ECG, while $24 \%$ reported that they very frequently used medical apps for ECG. The most likely reason for the high use of applications on ECG training was thought to be the high rate of atypical or subclinical acute coronary syndrome cases, especially in emergency departments, and the fact that ECG is 
used as a diagnostic tool not only for acute coronary syndrome but also for many other diseases.

Medical students know that developing their radiological imaging evaluation skills is highly positive and beneficial for their future careers $(18,19)$. The best way to learn radiological information is to find a balance between memorising, visualising and understanding (20). One of the most common reasons for the use of medical apps in the emergency department is the evaluation of radiological imaging results, and the fact that radiological images are commonly used as a diagnostic/differential diagnostic tool in the emergency department. This suggests that the students felt the need to repeat and visualize the information they previously received in their courses.

It was found that the students occasionally used the medical apps for evaluating cases and preparing for the specialty exams they will take after graduation. This is thought to be due to the fact that the final year medical curriculum consists mostly of practical courses, which somewhat distances the students from theoretical education due to the higher number of patients they have to evaluate. This leads the students to look out for practical training on topics that are more directly related to their patients, such as treatment, ECG evaluation and drug dose.

In their study on the senior students of a university medical school in Kenya, Masika et al. found that $31 \%$ of the students never used applications containing medical calculators (11). In our study, we found that $52 \%$ of the students in the emergency medical training programme never used applications containing medical calculators. In their study, Masika et al. found that $13 \%$ of the students never used applications containing medical dictionaries (11). Similarly, we also found that $14 \%$ of the students in the emergency medical training programme never used software containing medical dictionaries. Furthermore, in their study published in 2012, Payne et al. found that $47.8 \%$ of medical students never used applications containing clinical score/medical calculator apps (12). In our study, it was found that the ratio of students who never used applications containing medical calculators (which are an integral part of practice in emergency medical training) was $52 \%$. The probable reason for the less frequent use of applications containing medical dictionaries, anatomical information and medical calculators by the students during their emergency medical training is the fact that these topics are of a more theoretical nature, and that they are not used heavily in bedside practices.

It was found that students generally had positive opinions about medical apps, with the students expressing that these applications contributed to their education, that these applications increased their medical knowledge, and that they would continue to use these applications after graduation. The positive opinions found in this study were similar to the ones reported in previous studies $(8,13)$. As a negative opinion, students expressed their annoyance at the advertisements in medical apps. Interestingly, $42 \%$ of the students disagreed with the view that medical apps reduce the need for course books/lecture notes. Medical app use among senior year medical faculty students is increasing.

Medical apps are frequently used during emergency medical training, and students tend to utilize applications on drug information, ECG and radiological evaluation more frequently than applications containing medical dictionaries, anatomical information and medical calculators. This may be due to the fact that there is a greater need for these applications in clinical practice, or it may be due to students considering themselves as inadequate or lacking competency in these subjects. We think that increasing the amount of training in the areas of drugs, ECG and radiological evaluation, in particular, will be more beneficial for the students.

\section{References}

1. Franko OI, Tirrell TF. Smartphone app use among medical providers in ACGME training programs. Journal of medical systems 2012; 36(5): 3135-3139.

2. Ho K, Lauscher HN, Broudo M, Jarvis-Selinger S, Fraser J, Hewes D, et al. The impact of a personal digital assistant (PDA) case $\log$ in a medical student clerkship. Teaching and learning in medicine 2009; 21(4): 318-326.

3. Kurth RJ, Silenzio V, Irigoyen MM. Use of personal digital assistants to enhance educational evaluation in a primary care clerkship. Medical teacher 2002; 24(5): 488-490.

4. Lasserre K, Eley D, Baker P, Kruesi L. Medical students out of town but not out of touch: Use of personal digital assistants to improve access to clinical information and enhance learning at the point of care in rural and remote Australia. Australian Journal of Rural Health 2010; 18(2): 87-88.

5. Wu RC, Morra D, Quan S, Lai S, Zanjani S, Abrams $\mathrm{H}$, et al. The use of smartphones for clinical communication on internal medicine wards. Journal of Hospital Medicine 2010; 5(9): 553-559.

6. Davies BS, Rafique J, Vincent TR, Fairclough J, Packer MH, Vincent R, et al. Mobile Medical Education (MoMEd)-how mobile information resources contribute to learning for undergraduate 
clinical students-a mixed methods study. BMC medical education 2012; 12(1): 1.

7. Low D, Clark N, Soar J, Padkin A, Stoneham A, Perkins GD, et al. A randomised control trial to determine if use of the iResus $($ application on a smart phone improves the performance of an advanced life support provider in a simulated medical emergency. Anaesthesia 2011; 66(4): 255262.

8. Sayedalamin Z, Alshuaibi A, Almutairi O, Baghaffar M, Jameel T, Baig M. Utilization of smart phones related medical applications among medical students at King Abdulaziz University, Jeddah: A cross-sectional study. Journal of infection and public health 2016; 9(6): 691-697.

9. Koehler N, Yao K, Vujovic O, McMenamin C. Medical students' use of and attitudes towards medical applications. Journal of mobile technology in medicine 2012; 1(4): 16-21.

10. Ozdalga E, Ozdalga A, Ahuja N. The smartphone in medicine: a review of current and potential use among physicians and students. Journal of medical Internet research 2012; 14(5): e128.

11. Masika MM, Omondi GB, Natembeya DS, Mugane EM, Bosire KO, Kibwage IO. Use of mobile learning technology among final year medical students in Kenya. Pan African Medical Journal 2015; 21(1).

12. Payne KFB, Wharrad H, Watts K. Smartphone and medical related App use among medical students and junior doctors in the United Kingdom (UK): a regional survey. BMC medical informatics and decision making 2012; 12(1): 121.

13. Wallace S, Clark M, White J. 'It's on my iPhone': attitudes to the use of mobile computing devices in medical education, a mixed-methods study. BMJ open 2012; 2(4): e001099.

14. Yalçınoğlu N, Kayı İ, Işık Ş, Aydın T, Zengin Ş, Karabey S. The views of intern doctors on medical education in İstanbul Faculty of Medicine, İstanbul University. İstanbul Tip Fakültesi Dergisi 2012; 75: 41-45.

15. Boruff JT, Storie D. Mobile devices in medicine: a survey of how medical students, residents, and faculty use smartphones and other mobile devices to find information. Journal of the Medical Library Association: JMLA 2014; 102(1): 22.

16. Little B, Mainie I, Ho K, Scott L. Electrocardiogram and rhythm strip interpretation by final year medical students. The Ulster medical journal 2001; 70(2): 108.

17. Nilsson M, Bolinder G, Held C, Johansson B-L, Fors U, Östergren J. Evaluation of a web-based ECG-interpretation programme for undergraduate medical students. BMC medical education 2008; 8(1): 25.

18. Nyhsen CM, Steinberg LJ, O’Connell JE. Undergraduate radiology teaching from the student's perspective. Insights into imaging 2013; 4(1): 103-109.

19. Binder J, Krautz C, Engel K, Grützmann R, Fellner FA, Burger $\mathrm{PH}$, et al. is Leveraging medical imaging for medical education-A cinematic rendering-featured lecture. Annals of Anatomy-Anatomischer Anzeiger 2019; 222: 159165.

20. Pandey P, Zimitat C. Medical students' learning of anatomy: memorisation, understanding and visualisation. Medical education 2007; 41(1): 7-14. 